\title{
IMPLEMENTATION OF ISLAMIC RELIGIOUS EDUCATION LEARNING IN HIGHER EDUCATION ON THE PANDEMIC PERIOD
}

\author{
Siti Maryam Munjiat \\ Fakultas Ilmu Tarbiyah dan Keguruan Institut Agama Islam Negeri Syekh Nurjati Cirebon, \\ Indonesia \\ siti.maryam.munjiat@syekhnurjati.ac.id
}

Received: 06-04-2020

Revised: 06-07-2020

Accepted: 23-07-2020

\begin{abstract}
This study aims to explain and describe the implementation of PAI learning in higher Education institutions during the pandemic. This research method uses qualitative research with a case study approach and research design using analytical descriptives. The place of this research was at the KH Abdul Chalim Pacet Mojokerto Islamic Boarding School Institute during the pandemic from mid-March to May 2020. The results of the study: 1) online PAI learning planning should look at the condition of lecturers and students regarding the ability to conduct online lectures. Lecturers are given the freedom to conduct online lectures using any media as long as it is useful and learning outcomes can be maximized. 2) the implementation of PAI learning is carried out online through lecture and discussion methods. 3) Evaluation of PAI learning in Higher Education includes: a) student activity and discipline in carrying out learning b) assignments to students in the form of presentations, working on papers, c) midterm examinations d) written examinations and assignments at the end of the semester.

Keywords: PAI Learning, Higher Education, Pandemic Periode

\section{Abstrak}

Penelitian ini bertujuan untuk menjelaskan dan mendeskripsikan implementasi pembelajaran PAI di Perguruan tinggi ketika masa pandemi. Metode peneitian ini menggunakan jenis penelitian kualitatif dengan pendekatan studi kasus dan desain penelitian menggunakan deskriptip analitis. Tempat penelitian ini di Institut Pesantren KH Abdul Chalim Pacet Mojokerto selama pandemi dari pertengahan maret bingga Mei 2020. Hasil penelitian: 1) perencanaan pembelajaran PAI secara online harus melihat kondisi dosen dan mahasiswa terkait kemampuan untuk melakukan kuliab online. Dosen diberikan keleluasaan untuk melakukan kuliah online dengan memakai media apapun asalkan berguna dan capain pembeajaran bisa maksimal. 2) pelaksanaan pembelajaran PAI dilaksanakan dengan online melalui metode ceramah dan diskusi. 3) Evaluasi pembelajaran PAI di Perguruan Tinggi meliputi: a) keaktifan dan kedisiplinan mahasiswa dalam melaksanakan pembelajaran b) tugas kepada mahasiswa berupa presentasi, mengerjakan makalah, c) ujian tengab semester d) ujian tulis dan penugasan pada akhir semester.
\end{abstract}

Kata Kunci: Pembelajaran PAI, Perguruan Tinggi, Masa Pendemi 


\section{INTRODUCTION}

Islamic Religious Education (PAI) learning is the process of interaction between teachers and students to achieve learning objectives ${ }^{1}$. Whereas PAI learning in higher education is not just a transfer of khowledge but has two goals, namely that students are able to apply in daily life and become students' provisions to teach when they graduate 2 . PAI learning so far has constraints, namely: 1) PAI learning is only at the cognitive level and has not changed at the level of meaning or value 2) lack of cooperation with non-religious education 3) and less relevant to social and cultural contextual changes ${ }^{3}$. One obstacle that is currently difficult to overcome is that PAI learning is less responsive to social change as it is today, when the WHO Word Healt Organization issued a pandemic status ${ }^{4}$, the President appealed and the Minister of Education issued decree no. 3 and 4 in $2020^{5}$ to learn and work from home or independently. online then this becomes a problem again for learning PAI.

In general, the obstacles to PAI learning above are compounded by the ineffectiveness of online learning due to limited infrastructure owned by each tertiary institution and institution ${ }^{6}$. It was also stated by Suryani that online learning decreases student learning interest ${ }^{7}$. Students' perceptions say that online learning seems boring and saturating so that lecturers and teachers are expected to be able to provide higher innovation and creativity ${ }^{8}$.

KH Abdul Chalim Mojokerto Islamic Boarding School Institute (Ikhac), a private university under the auspices of the Ministry of Religion, responded to the Minister of Education's decision to learn dan work from home. therefore since mid-March Ikhac has implemented full online learning. Seeing the Ikhac Rector's circular, the learning was fully carried out by the lecturer and reported the activity to the head of each of his study programs. Implementing online learning The Chancellor appealed to see the condition of lecturers and

\footnotetext{
${ }^{1}$ Tri Hartono and Dhenis Agus Saputro, 'Pengembangan Desain Pembelajaran PAI Di Pondok Pesantren Kreatif Agro Nuur El-Falah Salatiga', Nazhruna: Jurnal Pendidikan Islam 2, no. 2 (26 August 2019): 290-309, https://doi.org/10.31538/nzh.v2i2.331; Moh. Wardi, Ismail Ismail, and Ali Makki, 'Perbandingan Pendidikan; Pemahaman Simbolis Dan Substantif PAI Di Madrasah Dan PAI Di Sekolah Umum', Nidhomul Haq: Jurnal Manajemen Pendidikan Islam 4, no. 1 (7 March 2019): 23-33, https://doi.org/10.31538/ndh.v4i1.104.

${ }^{2}$ Muhammad Amin Abdullah, 'Islamic Studies in Higher Education in Indonesia: Challenges, Impact and Prospects for the World Community', Al-Jami'ab: Journal of Islamic Studies 55, no. 2 (15 December 2017): 391-426, https://doi.org/10.14421/ajis.2017.552.391-426; Ade Yeti Nuryantini, Karman K, and Abdul Holik, 'Integration Science and Religion: An Analysis in Islamic Higher Education', TARBIY A: Journal of Education in Muslim Society 5, no. 1 (22 November 2018): 11-18, https://doi.org/10.15408/tjems.v5i1.9508.

${ }^{3}$ Muhaimin, Rekonstruksi Pendidikan Islam: Dari Paradigma Pengembangan, Manajemen Kelembagaan, Kurikulum Hingga Strategi Pembelajaran (Jakarta: Raja Grafindo Persada, 2009).

4 'The WHO Just Declared Coronavirus COVID-19 a Pandemic', Time, accessed 8 June 2020, https://time.com/5791661/who-coronavirus-pandemic-declaration/.

5 'Surat Edaran Pencegahan COVID-19 Pada Satuan Pendidikan', Kementerian Pendidikan dan Kebudayaan, 10 March 2020, https://www.kemdikbud.go.id/main/blog/2020/03/surat-edaran-pencegahancovid19-pada-satuan-pendidikan.

6 Roman Andrianto Pangondian, Paulus Insap Santosa, and Eko Nugroho, 'Faktor - Faktor Yang Mempengaruhi Kesuksesan Pembelajaran Daring Dalam Revolusi Industri 4.0', Seminar Nasional Teknologi Komputer \& Sains (SAINTEKS) 1, no. 1 (21 February 2019), https://www.prosiding.seminarid.com/index.php/sainteks/article/view/122.

${ }^{7}$ Yulinda Erma Suryani, 'Kesulitan Belajar', Magistra 22, no. 73 (2010): 33.

8 Aswasulasikin Aswasulasikin, 'Persepsi Mahasiswa Terhadap Kuliah Daring di Masa Pandemi Corona Virus Disease (COVID-19)', SALAM: Jurnal Sosial dan Budaya Syar-i 7, no. 8 (25 May 2020), https://doi.org/10.15408/sjsbs.v7i8.15734.
} 
students so that Ikhac provides the freedom to use online learning platforms that make it easier.

As prospective teachers are not only required to be experts in delivering material / teaching materials offline (face to face in class), but are also required to be able to use an online learning system 9 . Some obstacles will certainly be found in the online learning process, so students in general must find their own solutions to the obstacles they face ${ }^{10}$. Various obstacles found during the online learning process can affect the psychological condition of students, so it is necessary to have a solution to these obstacles, for example the ability to manage stress faced. This condition is interesting to study considering that this online learning system was first carried out by all students simultaneously ${ }^{11}$.

Technology cannot completely replace lecturers' tasks such as conducting face-to-face learning. However, this situation must be overcome by lecturers and students so that learning gets maximum results. UIN Bandung survey research explains that lecturers conduct online learning in various ways such as using google classroom, zoom application, whatsapp and others ${ }^{12}$. The obstacles faced by lecturers and students are very varied, which means it is not like doing face-to-face learning. From some of the information above, the authors try to describe the application of PAI learning at the KH Abdul Chalim Pacet Mojokerto Islamic Institute.

\section{RESEARCH METHOD}

This research uses qualitative research with a case study approach. The research design uses descriptive analytic that is to explain the results of field research descriptively and analyze with relevant theories and the results of previous studies ${ }^{13}$. This research is located at the $\mathrm{KH}$ Abdul Chalim Pacet Mojokerto Islamic Boarding School Institute for Interdisciplinary Islamic Religious Education Program. The informants of this research are lecturers who teach at PAI study programs, especially lecturers who are given Islamic Education courses. According to Yin $^{14}$ said that "the case study is a naturalistic research that investigates phenomena in the context of real life and utilizes multi-source evidence sources" and data collection techniques that is by observing participation, researchers participate in all activities at the $\mathrm{KH}$ Abdul Chalim Mojokerto Islamic Boarding School Instititute. Researchers conducted interviews from various lecturer, staff, student and campus management sources. Interviews conducted in an informal condition so that the data acquisition is more comprehensive. Analysis of the data of this study follows what was suggested by Miles and Hubberman, namely: Data reduction, data

${ }^{9}$ Ahmad Saiful Mirza et al., 'Digital Technology on Millenial Generation : Potere Mobile Devices on Primary Students for Supporting Learning' (International Conference on Science and Education and Technology 2018 (ISET 2018), Atlantis Press, 2018), https://doi.org/10.2991/iset-18.2018.9.

${ }^{10}$ Henry Praherdhiono et al., Implementasi Pembelajaran Di Era Dan Pasca Pandemi Covid-19 (Seribu Bintang, 2020).

${ }^{11}$ Dindin Jamaluddin et al., 'Pembelajaran daring masa pandemik Covid-19 pada calon guru: hambatan, solusi dan proyeksi', LP2M, 21 April 2020, http://digilib.uinsgd.ac.id/30518/.

${ }^{12}$ Jamaluddin et al.

${ }^{13}$ John W. Creswell, Qualitative Inquiry \& Research Design: Choosing among Five Approaches, 2nd ed (Thousand Oaks: Sage Publications, 2007).

${ }^{14}$ Robert K Yin, Case Study Research: Design and Methods, 2013, 4. 
presentation and conclusion drawing ${ }^{15}$. This research was conducted when the WHO issued covid-19 pandemic status ${ }^{16}$ and appealed to the president and Minister of Education Nadiem Anwar Makarim ${ }^{17}$ to study at home or study online. In the Ikhac Mojokerto Institute lecture calendar starting on March 192020 until the end of the semester exams on May 29, 202018.

\section{Theory}

Implementation is a process of applying ideas, concepts, policy, or innovation in a practical action so as to have an impact, whether in the form of changes in knowledge, skills, values and attitudes ${ }^{19}$. Meanwhile, according to Hamzah B Uno the implementation of learning is to apply the process of interaction between educators and students and learning resources in the learning environment and copy information exchange ${ }^{20}$. Implementation aside from being seen as a process, implementation is also seen as implementing an innovation and always giving birth to changes towards innovation or improvement, implementation can take place continuously over time. Nana Syaodih said that the implementation process had at least three stages or steps that had to be carried out, namely: the planning, implementation and evaluation stages ${ }^{21}$.

The learning of Islamic Education in Higher Education in question is the interaction between lecturers and students who study Islamic education materials. according to Ahmad Tafsir $^{22}$ that PAI learning is a process of a person to understand Islamic education materials such as fiqh, hadith, the history of Islam and Aqeedah. While the learning objectives of PAI in higher education are for students' skills as provisions for teaching in schools and for their ability to apply them in everyday life. Islamic Religious Education Learning (PAI) in schools is teaching and learning process in which there is interaction and reciprocity between the teacher as a facilitator or transferring knowledge and scholarship as recipients of knowledge that is consciously carried out in a formal environment that is the school ${ }^{23}$.

\section{RESULT AND DISCUSSION}

The implementation of PAI learning in higher education follows what was suggested by Nana Syaodih ${ }^{24}$ who has stages of learning planning, learning implementation and learning evaluation. The data presented here when Ikhac tertiary institutions follow government

\footnotetext{
${ }^{15}$ Matthew B. Miles, A. M. Huberman, and Johnny Saldaña, Qualitative Data Analysis: A Methods Sourcebook, Third edition (Thousand Oaks, Califorinia: SAGE Publications, Inc, 2014).

16 'The WHO Just Declared Coronavirus COVID-19 a Pandemic'.

17 'Surat Edaran Pencegahan COVID-19 Pada Satuan Pendidikan'.

18 'Surat Edaran Rektor Ikhac Tentang Belajar Dirumah' (Ikhac Mojokerto, 2020).

19 Abdullah Idi, Pengembangan kurikulum: teori dan praktik, 2nd ed. (Jakarta: Raja Grafindo Persada, 2016), 324.

${ }^{20}$ Uno Hamzah B, Profesi Kependidikan: Problema, Solusi, Dan Reformasi Pendidikan Di Indonesia, Cet. 1 (Jakarta: Bumi Aksara, 2007); St Marwiyah BK Alauddin \& Muh Khaerul Ummah, Perencanaan Pembelajaran Kontemporer Berbasis Penerapan Kurikulum 2013 (Deepublish, 2018).

${ }^{21}$ Nana Syaodih Sukmadinata and Muchlis, Pengembangan kurikulum: teori dan praktik (Bandung: PT Remaja Rosdakarya, 1997).

${ }^{22}$ Ahmad Tafsir, Ilmu Pendidikan Islami, Cet. 1 (Bandung: Remaja Rosdakarya, 2012).

${ }^{23}$ Abdurrohman Abdurrohman and Huldiya Syamsiar, 'Pembelajaran Pendidikan Agama Islam (PAI) Model Keberagamaan Inklusif Untuk Mencegah Radikalisme Beragama Dikalangan Siswa SMA', Fenomena 9, no. 1 (1 June 2017): 105, https://doi.org/10.21093/fj.v9i1.789.

${ }^{24}$ Sukmadinata and Muchlis, Pengembangan kurikulum.
} 
regulations work form home mid-March to June 2020. the following will be the author's description.

\section{PAI Learning Planning}

Learning Planning is to arrange the steps that will be implemented to achieve the specified goals. The plan can be arranged based on needs within a certain period in accordance with the wishes of the planning maker ${ }^{25}$. But more important is the planning made must be carried out easily and on target. In the context of PAI learning ${ }^{26}$, planning can be interpreted as the process of preparing material, learning, the use of instructional media, the use of learning approaches and methods, assessment in the allocation of time that will be carried out at a certain time to achieve predetermined objectives ${ }^{27}$.

In Permendikbud regulation No. 49 of 2014 concerning National Standards for Higher Education article 12 states that the Semester Learning Planning (RPS) contains at least some of the following components adjusted to the PAI lecturer RPS Ikhac Mojokerto Institute 28 .

Tabel: 1. RPS: Semester Learning Planning

\begin{tabular}{ll}
\hline Study Program & Islamic education study program \\
\hline Course & PAI Curricullum Development \\
Semester & Even 2019-2020 \\
Lecturer Name & Abdur Rohim, M.Pd.I \\
Graduate Learning Outcomes & Students are able to understand the concept of \\
& curriculum development (including the Islamic \\
& Education curriculum), and have academic skills that are \\
& useful as provisions for teaching and developing the PAI \\
& curriculum in madrasas / schools. \\
Meeting Learning Outcomes & Understanding the nature of the curriculum in education \\
Indicator & The nature of curriculum in education: curriculum \\
Study material & interpretation, curriculum and learning, curriculum as a \\
& discipline \\
Lecturing, Discovery learning, Classroom Discusion \\
Time & 90 minute \\
Learning experience & - Listen to lecturer material delivery through lectures \\
& and power points. \\
\hline
\end{tabular}

${ }^{25}$ Oemar Hamalik, Perencanaan pengajaran berdasarkan pendekatan sistem (Jakarta, Indonesia: Bumi Aksara, 2003); Afiful Ikhwan, 'Manajemen Perencanaan Pendidikan Islam (Kajian Tematik Al-Qurâ€TMan Dan Hadist)', Edukasi: Jurnal Pendidikan Islam 4, no. 1 (1 June 2016): 128-55, http://ejournal.staimtulungagung.ac.id/index.php/EDUKASI/article/view/194.

${ }^{26}$ Munirah Munirah, 'Pendidikan Islam Dalam Perspektif Hadis', Lentera Pendidikan: Jurnal Ilmu Tarbiyah dan Keguruan 19, no. 2 (1 January 2017): 209-22, https://doi.org/10.24252/lp.2016v19n2a7.

27 Jonathan Savage, Lesson Planning: Key Concepts and Skills for Teachers (Routledge, 2014); Rudi Ahmad Suryadi dan Aguslani Mushlih, Desain Dan Perencanaan Pembelajaran (Deepublish, 2019).

${ }^{28}$ Rahmat, Wawancara Ketua Prodi PAI Ikhac, 2020. 
material

Indicator Criteria

Reference list
Presence, participation, discussion, critical power and ethics.

1. S. Nasution, Pengembangan Kurikulum

2. Moh Ali, Pengembangan kurikulum di Sekolah

3. Subandiyah. Pengembangan kurikulum disekolah.

4. Asri Budiningsih, Sejarah Kurikulum sekolah di Indoensia

5. Omar hamalik, Pembinaan dan pengembangan kurikulum

6. Ralph Tyler, Basic Principles of Curriculum and Instruction

Source: PAI Study Program Documentation

PAI learning planning in Ikhac Mojokerto Institute is carried out before the pandemic means that when the pandemic is declared by WHO and a learning decision from home by the Minister of Education Nadim Makarim then automatically the planning of PAI learning in tertiary institutions must adjust to these conditions. From the results of interviews with several PAI lecturers in Ikhac Mojokerto that the PAI learning plan must still be carried out but it follows the conditions of the students and lecturers. The pandemic made it difficult for some lecturers to learn because some lecturers were not innovative enough to do previous learning.

PAI learning planning during the pandemic has changed in several aspects, namely the learning method which was originally free to face-to-face online and has its own constraints for lecturers and students. Some PAI lecturers also change the implementation schedule or lecture time so that many students find it difficult to follow the rhythm given by the lecturer. Less optimal learning outcomes because lecturers cannot directly assess the affective and psychomotor aspects of students. From the other side, many PAI lecturers also found innovations to do online learning on YouTube and other social media accounts, which were initially unthinkable.

\section{Implementation of PAI Learning}

The most supportive application of PAI learning in higher education is the educator factor $^{29}$. Innovative educators will be able to provide maximum learning and be able to do varied methods ${ }^{30}$. Educators are able to see the condition of students socially and

${ }^{29}$ E Mulyasa, Menjagi Guru Profesional Menciptakan Pembelajaran Kreatif dan Menyenangkan, 11th ed. (Bandung: Rosdakarya, 2011); Zainal Aqib, Menjadi guru profesional berstandar nasional: memuat standar nasional pendidikan UURI no. 20/2003 (Sisdiknas), UURI no. 14/2005 (guru dan dosen), PPRI no. 19/2005 (standar nasional pendidikan), PPRI no. 74/2008 (guru), delapan permendiknas (standar nasional pendidikan), Permendiknas no. 10/2009 (sertifikasi bagi guru dalam jabatan), Permendiknas no. 36/2007 (penyaluran tunjangan profesi bagi guru), Permendiknas no. 39/2008 (pembinaan kesiswaan) (Yrama Widya, 2009); Muhammad Anas Ma’arif, 'Analisis Konsep Kompetensi Kepribadian Guru PAI Menurut Az-Zarnuji', ISTAWA $2, \quad$ no. 2 (2017): http://journal.umpo.ac.id/index.php/istawa/article/view/624; Hamid Darmadi, 'Tugas, Peran, Kompetensi, Dan Tanggung Jawab Menjadi Guru Profesional', Edukasi: Jurnal Pendidikan 13, no. 2 (23 April 2016): 161-74, https://doi.org/10.31571/edukasi.v13i2.113.

${ }^{30}$ Beatrice Avalos, 'Chapter 9 Teacher Professional Development in Teaching and Teacher Education', in From Teacher Thinking to Teachers and Teaching: The Evolution of a Research Community, vol. 19, 0 vols, Advances in Research on Teaching 19 (Emerald Group Publishing Limited, 2013), 175-204, https://doi.org/10.1108/S14793687(2013)0000019012; Sri Sarjana, 'Education Reward for Teacher: Implementation Strategy to Improve Teacher' Performance', TARBIYA: Journal of Education in Muslim Society 3, no. 2 (29 December 2016): 205-17, 
psychologically so as to be able to make the learning atmosphere feel comfortable ${ }^{31}$. Learning a pandemic will not make difficulties for lecturers if they become innovative and creative educators. Some lecturers at PAI Ikhac Mojokerto Institute study PAI learning online with various variables such as online zoom media, google classroom and simply using whatsapp.

Conducting PAI learning online makes some economically disadvantaged students unable to carry out online learning to the maximum. Students who are outside the island of Java also find it difficult to get internet access when doing online learning directly. In fact, there are some students when conducting midterm exams are unable to do the task by writing in Microsoft Word because they do not have a laptop. Besides difficulties, there are also creative lecturers and students, they are able to create YouTube and Instagram accounts to do learning. Such as Mr. Husnur Rofiq ${ }^{32}$ doing live learning via YouTube. From some of the problems above, there are characteristics of the application of PAI learning in Higher Education as follows:

Tabel. 2

\begin{tabular}{|c|c|}
\hline \multicolumn{2}{|c|}{ Implementation of PAI Learning } \\
\hline Normal & Periode Pandemic covid-19 \\
\hline $\begin{array}{l}\text { 1. Make Semester Lecture Plans } \\
\text { (RPS) and send them to staff for } \\
\text { filing }\end{array}$ & $\begin{array}{l}\text { 1. Make Semester Lecture Plans (RPS) } \\
\text { and send them to staff for filing. } \\
\text { Difference when implementing RPS }\end{array}$ \\
\hline $\begin{array}{l}\text { 2. Conduct lectures in person (face to } \\
\text { face) }\end{array}$ & $\begin{array}{l}\text { 2. Online lectures, Lecturers are free to } \\
\text { use learning media that makes it easy } \\
\text { for students to attend online lectures. }\end{array}$ \\
\hline $\begin{array}{l}\text { 3. Methods of discussion, lecture and } \\
\text { assignment }\end{array}$ & $\begin{array}{l}\text { 3. Methods of discussion, lecture and } \\
\text { assignment }\end{array}$ \\
\hline $\begin{array}{l}\text { 4. Directly evaluate semester exams } \\
\text { by doing paperwork }\end{array}$ & $\begin{array}{l}\text { 4. Paperless. Students perform } \\
\text { assignments and lecturer assignments }\end{array}$ \\
\hline $\begin{array}{l}\text { 5. Lecturers can assess attitudes that } \\
\text { are seen directly student personal, } \\
\text { ethics and discipline }\end{array}$ & $\begin{array}{l}\text { 5. Lecturers have difficulty identifying } \\
\text { student attitudes and discipline }\end{array}$ \\
\hline $\begin{array}{l}\text { 6. Learning output: lecturers see } \\
\text { directly and easily assess students } \\
\text { cognitive, affective and } \\
\text { psychomotor. }\end{array}$ & $\begin{array}{l}\text { 6. Learning output: lecturers only assess } \\
\text { cognitive tasks from students. }\end{array}$ \\
\hline
\end{tabular}

Source: data analize

https://doi.org/10.15408/tjems.v3i2.4390; Muhammad Zulqarnain, 'An Investigation of Teacher-Student Relationship in Islamic History of Education', TARBIY A: Journal of Education in Muslim Society 4, no. 1 (19 June 2017): 13-21, https://doi.org/10.15408/tjems.v4i1.5317.

${ }^{31}$ Darmadi, 'Tugas, Peran, Kompetensi, Dan Tanggung Jawab Menjadi Guru Profesional'; Nurul lail Rosyidatul Mu'ammaroh, 'Antara Profesi, Kompetensi Dan Tugas Kependidikan Seorang Guru', Madrasah 7, no. 1 (29 January 2016): 18, https://doi.org/10.18860/jt.v7i1.3305.

32 Rofiq Husnur, Wawancara Dosen Prodi PAI Ikhac, 2020. 


\section{Evaluation of PAI Learning}

PAI Study Program of Ikhac Mojokerto's Institute evaluates in the middle of the semester and at the end of the semester. Lecturers are given full authority to provide assessments and assignments to students. Lecturer assessments include: 1) student activity and discipline in carrying out learning 2) assignments to students in the form of presentations, working on papers, 3) midterm examinations 3) written examinations and assignments at the end of the semester. Evaluation of PAI learning can run optimally if the lecturers and students work well together. Evaluations change instantly when covid-19 pandemic hits the whole world. Lecturers can no longer make and assess students to the fullest. Evaluation is constrained because the online learning process is also constrained. Therefore the evaluation carried out by PAI lecturers is only limited to cognitive assessment.

For example, Rofiq's ${ }^{33}$ presentation in conducting PAI learning evaluation in tertiary institutions only relied on student assignments when conducting online presentations, midterms and final semester exams. Discipline and ethics are hardly touched at all. Yet according to Kholidah in PAI learning ${ }^{34}$, ideally learning approaches are used that are capable of accommodating cognitive, affective, and psychomotor aspects. PAI learning in the era of the pesticide should have no obstacles if the lecturer works maximally. This of course requires hard work of lecturers, students and institutions so that stakeholders are able to implement the system to the full and full responsibility. Above it has been mentioned that online learning will make students bored and boring if lecturers are less innovative in implementing learning. When lecturers are less creative in implementing online learning, the learning process will not be maximized so that evaluation in learning is also not optimal.

\section{CONCLUSSION}

Implementation of PAI learning in Higher Education during the covid-19 pandemic carried out at the PAI Study Program of Islamic Boarding School KH Abdul Chalim Pacet Mojokerto Institute through three stages namely: 1) Learning planning 2) Implementation of learning and 3) Evaluation of learning. The planning phase includes: a) the readiness of the infrastructure of lecturers and students carrying out online learning in accordance with the semester learning plan (RPS), b) the learning achievements must be in accordance with the specified targets so that lecturers and students can make maximum learning. The implementation phase of PAI learning includes: a) lecturers and students have the right to determine the media / tools made for learning b) learning methods using lectures, discussions and assignments, c) lecturers are required to be creative so that students are not bored and bored in learning activities. The evaluation phase of PAI learning includes: a) the activeness and discipline of students in carrying out learning, b) assignments to students in the form of presentations, working on papers, c) midterm exams, d) written examinations and assignments at the end of the semester.

\footnotetext{
${ }^{33}$ Husnur.

34 Amin A. Rifqi, Sistem Pembelajaran Pendidikan Agama Islam pada Perguruan Tinggi Umum (Deepublish, 2015).
} 
Siti Maryam Munjiat

\section{REFERENCES}

A. Rifqi, Amin. Sistem Pembelajaran Pendidikan Agama Islam pada Perguruan Tinggi Umum. Deepublish, 2015.

Abdullah, Muhammad Amin. 'Islamic Studies in Higher Education in Indonesia: Challenges, Impact and Prospects for the World Community'. Al-Jami'ab: Journal of Islamic Studies 55, no. 2 (15 December 2017): 391-426. https://doi.org/10.14421/ajis.2017.552.391426.

Abdurrohman, Abdurrohman, and Huldiya Syamsiar. 'Pembelajaran Pendidikan Agama Islam (PAI) Model Keberagamaan Inklusif Untuk Mencegah Radikalisme Beragama Dikalangan Siswa SMA'. Fenomena 9, no. 1 (1 June 2017): 105. https://doi.org/10.21093/fj.v9i1.789.

Aqib, Zainal. Menjadi guru profesional berstandar nasional: memuat standar nasional pendidikan UURI no. 20/2003 (Sisdiknas), UURI no. 14/2005 (guru dan dosen), PPRI no. 19/2005 (standar nasional pendidikan), PPRI no. 74/2008 (guru), delapan permendiknas (standar nasional pendidikan), Permendiknas no. 10/2009 (sertifikasi bagi guru dalam jabatan), Permendiknas no. 36/2007 (penyaluran tunjangan profesi bagi guru), Permendiknas no. 39/2008 (pembinaan kesiswaan). Yrama Widya, 2009.

Aswasulasikin, Aswasulasikin. 'Persepsi Mahasiswa Terhadap Kuliah Daring di Masa Pandemi Corona Virus Disease (COVID-19)'. SALAM: Jurnal Sosial dan Budaya Syar-i 7, no. 8 (25 May 2020). https://doi.org/10.15408/sjsbs.v7i8.15734.

Avalos, Beatrice. 'Chapter 9 Teacher Professional Development in Teaching and Teacher Education'. In From Teacher Thinking to Teachers and Teaching: The Evolution of a Research Community, 19:175-204. Advances in Research on Teaching 19. Emerald Group Publishing Limited, 2013. https://doi.org/10.1108/S1479-3687(2013)0000019012.

BK, St Marwiyah, Alauddin \& Muh Khaerul Ummah. Perencanaan Pembelajaran Kontemporer Berbasis Penerapan Kurikulum 2013. Deepublish, 2018.

Creswell, John W. Qualitative Inquiry \& Research Design: Choosing among Five Approaches. 2nd ed. Thousand Oaks: Sage Publications, 2007.

Darmadi, Hamid. 'Tugas, Peran, Kompetensi, Dan Tanggung Jawab Menjadi Guru Profesional'. Edukasi: Jurnal Pendidikan 13, no. 2 (23 April 2016): 161-74. https://doi.org/10.31571/edukasi.v13i2.113.

E Mulyasa. Menjagi Guru Profesional Menciptakan Pembelajaran Kreatif dan Menyenangkan. 11th ed. Bandung: Rosdakarya, 2011.

Hamalik, Oemar. Perencanaan pengajaran berdasarkan pendekatan sistem. Jakarta, Indonesia: Bumi Aksara, 2003.

Hamzah B, Uno. Profesi Kependidikan: Problema, Solusi, Dan Reformasi Pendidikan Di Indonesia. Cet. 1. Jakarta: Bumi Aksara, 2007.

Hartono, Tri, and Dhenis Agus Saputro. 'Pengembangan Desain Pembelajaran PAI Di Pondok Pesantren Kreatif Agro Nuur El-Falah Salatiga'. Nazhruna: Jumal Pendidikan Islam 2, no. 2 (26 August 2019): 290-309. https://doi.org/10.31538/nzh.v2i2.331.

Husnur, Rofiq. Wawancara Dosen Prodi PAI Ikhac, 2020.

Idi, Abdullah. Pengembangan kurikulum: teori dan praktik. 2nd ed. Jakarta: Raja Grafindo Persada, 2016. 
Implementation od Islamic Relegius Education Leraning in Higher Education,..

Ikhwan, Afiful. 'Manajemen Perencanaan Pendidikan Islam (Kajian Tematik Al-Qurâ $€^{\mathrm{TM}}$ an Dan Hadist)'. Edukasi: Jurnal Pendidikan Islam 4, no. 1 (1 June 2016): 128-55. http://ejournal.staim-tulungagung.ac.id/index.php/EDUKASI/article/view/194.

Jamaluddin, Dindin, Teti Ratnasih, Heri Gunawan, and Epa Paujiah. 'Pembelajaran daring masa pandemik Covid-19 pada calon guru: hambatan, solusi dan proyeksi'. LP2M, 21 April 2020. http://digilib.uinsgd.ac.id/30518/.

Ma'arif, Muhammad Anas. 'Analisis Konsep Kompetensi Kepribadian Guru PAI Menurut
Az-Zarnuji'.
ISTAWA
2, no.
2
(2017):
$35-60$.

http://journal.umpo.ac.id/index.php/istawa/article/view/624.

Miles, Matthew B., A. M. Huberman, and Johnny Saldaña. Qualitative Data Analysis: A Methods Sourcebook. Third edition. Thousand Oaks, Califorinia: SAGE Publications, Inc, 2014.

Mirza, Ahmad Saiful, Farid Ahmadi, Lysa Amorita Rachmawati, and Nashihah Laila Masruroh. 'Digital Technology on Millenial Generation: Potere Mobile Devices on Primary Students for Supporting Learning'. Atlantis Press, 2018. https://doi.org/10.2991/iset-18.2018.9.

Mu'ammaroh, Nurul lail Rosyidatul. 'Antara Profesi, Kompetensi Dan Tugas Kependidikan Seorang Guru'. Madrasah 7, no. 1 (29 January 2016): 18. https://doi.org/10.18860/jt.v7i1.3305.

Muhaimin. Rekonstruksi Pendidikan Islam: Dari Paradigma Pengembangan, Manajemen Kelembagaan, Kurikulum Hingga Strategi Pembelajaran. Jakarta: Raja Grafindo Persada, 2009.

Munirah, Munirah. 'Pendidikan Islam Dalam Perspektif Hadis'. Lentera Pendidikan : Jurnal Imu Tarbiyah dan Keguruan 19, no. 2 (1 January 2017): 209-22. https://doi.org/10.24252/lp.2016v19n2a7.

Mushlih, Rudi Ahmad Suryadi dan Aguslani. Desain Dan Perencanaan Pembelajaran. Deepublish, 2019.

Nuryantini, Ade Yeti, Karman K, and Abdul Holik. 'Integration Science and Religion: An Analysis in Islamic Higher Education'. TARBIY A: Journal of Education in Muslim Society 5, no. 1 (22 November 2018): 11-18. https://doi.org/10.15408/tjems.v5i1.9508.

Pangondian, Roman Andrianto, Paulus Insap Santosa, and Eko Nugroho. 'Faktor - Faktor Yang Mempengaruhi Kesuksesan Pembelajaran Daring Dalam Revolusi Industri 4.0'. Seminar Nasional Teknologi Komputer \& Sains (SAINTEKS) 1, no. 1 (21 February 2019). https://www.prosiding.seminar-id.com/index.php/sainteks/article/view/122.

Praherdhiono, Henry, Eka Pramono Adi, Yulias Prihatmoko, Nunung Nindigraha, Yerry Soepriyanto, Henny Indreswari, and Herlina Ike Oktaviani. Implementasi Pembelajaran Di Era Dan Pasca Pandemi Covid-19. Seribu Bintang, 2020.

Rahmat. Wawancara Ketua Prodi PAI Ikhac, 2020.

Sarjana, Sri. 'Education Reward for Teacher: Implementation Strategy to Improve Teacher' Performance'. TARBIY A: Journal of Education in Muslim Society 3, no. 2 (29 December 2016): 205-17. https://doi.org/10.15408/tjems.v3i2.4390.

Savage, Jonathan. Lesson Planning: Key Concepts and Skills for Teachers. Routledge, 2014.

Sukmadinata, Nana Syaodih, and Muchlis. Pengembangan kurikulum: teori dan praktik. Bandung: PT Remaja Rosdakarya, 1997. 
Siti Maryam Munjiat

Kementerian Pendidikan dan Kebudayaan. 'Surat Edaran Pencegahan COVID-19 Pada $\begin{array}{llll}\text { Satuan } & \text { Pendidikan', } & 10 & \text { March }\end{array}$ https://www.kemdikbud.go.id/main/blog/2020/03/surat-edaran-pencegahancovid19-pada-satuan-pendidikan.

'Surat Edaran Rektor Ikhac Tentang Belajar Dirumah'. Ikhac Mojokerto, 2020.

Suryani, Yulinda Erma. 'Kesulitan Belajar'. Magistra 22, no. 73 (2010): 33.

Tafsir, Ahmad. Ilmu Pendidikan Islami. Cet. 1. Bandung: Remaja Rosdakarya, 2012.

Time. 'The WHO Just Declared Coronavirus COVID-19 a Pandemic'. Accessed 8 June 2020. https://time.com/5791661/who-coronavirus-pandemic-declaration/.

Wardi, Moh., Ismail Ismail, and Ali Makki. 'Perbandingan Pendidikan; Pemahaman Simbolis Dan Substantif PAI Di Madrasah Dan PAI Di Sekolah Umum'. Nidhomul Haq : Jurnal Manajemen Pendidikan Islam 4, no. 1 (7 March 2019): 23-33. https://doi.org/10.31538/ndh.v4i1.104.

Yin, Robert K. Case Study Research: Design and Methods, 2013.

Zulqarnain, Muhammad. 'An Investigation of Teacher-Student Relationship in Islamic History of Education'. TARBIY A: Journal of Education in Muslim Society 4, no. 1 (19 June 2017): 13-21. https://doi.org/10.15408/tjems.v4i1.5317. 